\title{
The Genus Koilodepas Hassk. (Euphorbiaceae) in Malesia
}

\author{
MUZAYYINAH $^{1, \vartheta}$, EDI GUHARDJA ${ }^{2}$, MIEN A. RIFAl ${ }^{3}$, JOHANIS P. MOGEA $^{3}$, PETER VAN WALZEN ${ }^{4}$ \\ ${ }^{1}$ Program Study of Biological Education, Department of PMIPA FKIP Sebelas Maret University Surakarta 57126, Indonesia. \\ ${ }^{2}$ Department of Biology, Faculty of Mathematic and Sciences, Bogor Agriculture University, Bogor Indonesia \\ "Herbarium Bogoriense", Department of Botany, Research Center of Biology -LIPI, Bogor 16013, Indonesia \\ ${ }^{4}$ Rijksherbarium Leiden, The Netherlands.
}

Received: $8^{\text {th }}$ December 2003. Accepted: $17^{\text {th }}$ May 2004.

\begin{abstract}
The Malesian genus Koilodepas Hassk. has been revised based on the morphological and anatomical character using available herbarium collection in Herbarium Bogoriense and loan specimens from Kew Herbarium and Leiden Rijksherbarium. The present study is based on the observation of 176 specimens. Eight species has been recognized, namely $K$. bantamense, $K$. cordifolium, $K$. frutescns, $K$. homalifolium, $K$. laevigatum, $K$. longifolium, $K$. pectinatum, and two varieties within $K$. brevipes. The highest number of species is found in Borneo (5 species), three of them are found endemically in Borneo, K. cordisepalum endemically in Aceh, and K. homalifolium endemically in Papua New Guinea. A phylogenetic analysis of the genus, with Cephalomappa as outgroup, show that the species within the genus Koilodepas is in one group, starting with $K$. brevipes as a primitive one and $K$. bantamense occupies in an advance position.
\end{abstract}

(c) 2004 Jurusan Biologi FMIPA UNS Surakarta

Keyword: Koilodepas Hassk., Malesia, outgroup, phylogenetic analysis, outgroup.

\section{INTRODUCTION}

The genus Koilodepas belongs to the tribe Epiprineae of the subfamily Acalyphoideae. The characteristics of this tribe are flowers without a disk, pollen grains coarsely reticulate or perfora-tectate, indumentum stellate, inflexed in bud (except dorsifixed in Koilodepas), monoecious, pistillate calyx often accrescent, and seeds ecarunculate. The Epiprineae have been divided into two sub tribes Epiprinae and the monotypic Cephalomappinae (containing Cephalomappa). The characteristics of the sub tribe Epiprineae are: staminate calyx splitting into distinct segments, the pollen sexine rather coarsely reticulate, and the pistillate sepals often persistent and accrescent (Webster, 1994).

\section{MATERIAL AND METHODS}

\section{Material}

Material specimen of Koilodepas was collected in Malesia phytogeography area. The genus Koilodepas was presented based on 176 specimens from Kew Herbarium (K), the Rijksherbarium Leiden ( $L$ ) and the Herbarium Bogoriense (BO).

\footnotetext{
- Alamat korespondensi:

Jl. Ir. Sutami 31a, Surakarta 57126.

Tel. \& Fax.: +62-274-387781.

e-mail: yayin@uns.ac.id
}

\section{Methods}

The methods of research were morphological and leaf-anatomical description. The research had been used a large of herbarium specimens (i.e. 176 specimens) from Herbarium Bogoriense, Kew Herbarium, and Leiden Rijksherbarium. The material specimens were analyzed with Henning 86 programme.

\section{RESULT AND DISCUSSION}

\section{Morphology}

Characters like stipule shape, leaf margin, number of glands, hairs on the lower leaf surface, and flower morphology are used for the description of the species and for a study of the relationships within the genus.

\section{Stipules}

The genus has three forms of stipules, namely elliptical, deltoid, and angular. The margin of the stipules can either be pectinate, entire or serrate. The stipules of $K$. bantamense are triangular and the margin is serrate. The stipules of $K$. brevipes, $K$. cordisepalum, and $K$. homalifolium are triangular and the margin is entire. The shape of $K$. longifolium stipules is deltoid and the margins are entire or serrate. In $K$. laevigatum the stipules are deltoid and the margin is entire. The stipules of $K$. pectinatum are pectinate (Figure 1.). 


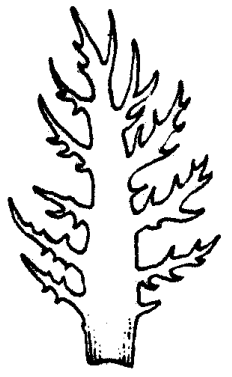

A

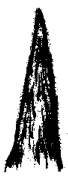

B

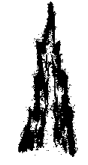

C

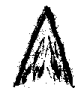

D

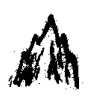

$\mathbf{E}$
Figure 1. Stipule's and margin of Koilodepas. A. elliptical and pectinate, B. entire, C. serrate, D. entire, E. serrate.
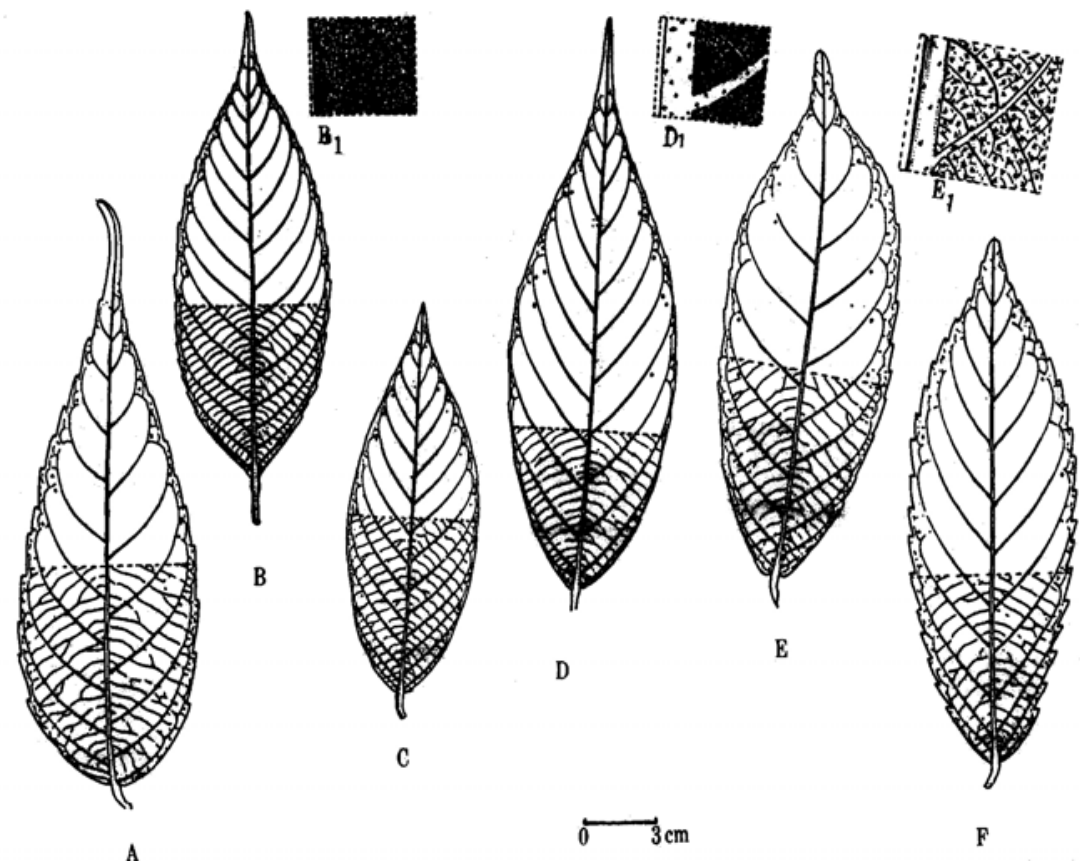

Figure 2. Leaf of Koilodepas Hassk. showing the margin. A. K. codisepalum (glabrous, serrate, caudate); B. K. pectinatum (hairy, serrate, caudate); B1. The density of stellate hairs on the lower surface; C. K. laevigatum (glabrous, entire, caudate); D. K. brevipes var. stenosepalum (hairy, serrate, caudate); D1. The density of stellate hairs on the lower surface; E. K. brevipes var. brevipes; E1. The density of stellate hairs on the leaf surface; F. K. homalifolium (glabrous, crenate, caudate).

in $\quad K$ bantamense, $K$. homalifolium, and $K$. frutescens. The texture of the lamina is chartaceous in $K$. laevigatum and $K$. homalifolium, subcoriaceous in $K$. bantamense, $K$. frutescens, $K$. brevipes, $K$. pectinatum, and $K$. cordisepalum, and coriaceous in K. Iongifolium. The tertiary venation is scalariform, except in $K$. cordisepalum, where it is reticulate (Figure 2.).

\section{Inflorescences}

The inflorescences are axillary racemous or branched spikes. The staminate flowers are arranged in glomerate heads. The bracts are cuneate with an entire margin and acute apex. The lobes of the calyx are acute and densely set with stellate long hairs. The number of stamens varies from 3 to 10. The filaments are basally united into an androphore. The filaments are subulate in $K$. laevigatum and obspathulate $\mathrm{n}$ the other species (Figure 3). The anthers are subapically dorsifixed.

The pistillate flowers are solitary. The shape of the sepal is somewhat different in each species. The sepals of $K$. pectinatum are free, foliolate, cordate, chartaceous, with 6-8 lobes, persistent, the margin serrate, but $K$. cordisepalum has smaller. The sepals of $K$. brevipes are free, subulate or elliptical, apex acute, 6-9 lobes, persistent. In $K$. longifolium are free, elliptical, and the apex obtuse. In K. bantamense, they are connate, 5-lobed, apex obtuse. The calyx of $K$. frutescens has 6 or 7 lobes. The styles are connate in $K$. bantamense, $K$. brevipes, $K$.

\section{Leaves}

The Leaves are simple, alternate, and elliptical. $K$. pectinatum and $K$. brevipes are hairy on the lower leaf surface, but $K$. laevigatum, $K$. homalifolium, $K$. bantamense, $K$. cordisepalum, and $K$. frutescens are glabrous. The leaf margin of $K$. homalifolium is crenate, when young crenulate. The leaf margin of $K$. laevigatum is entire, whereas in the other species it is serrate or dentate. A pair of glands is usually found at the lower surface, near the base of the leaves, but there are 3-7 pairs of glands in K. brevipes. The apex of the leaves is caudate, but acuminate to cuspidate longifolium, $K$. frutescens, $K$. homalifolium, and $K$. pectinatum, and free in $K$. cordisepalum and $K$. laevigatum (Figure 4.).

The number of stigmas is generally 3 , but $K$. bantamense and $K$. frutescens has 6 . The shape of the stigma is somewhat difference species, $K$. pectinatum, $K$. laevigatum, $K$. Pectinatum, $K$. cordisepalum, and $K$. brevipes have antennate stigmas; $K$. homalifolium and $K$. longifolium have multifid stigmas; $K$. frutescens and $K$. bantamense have coralliform. The stigma surface is stellately hairy (Figure 4.). 


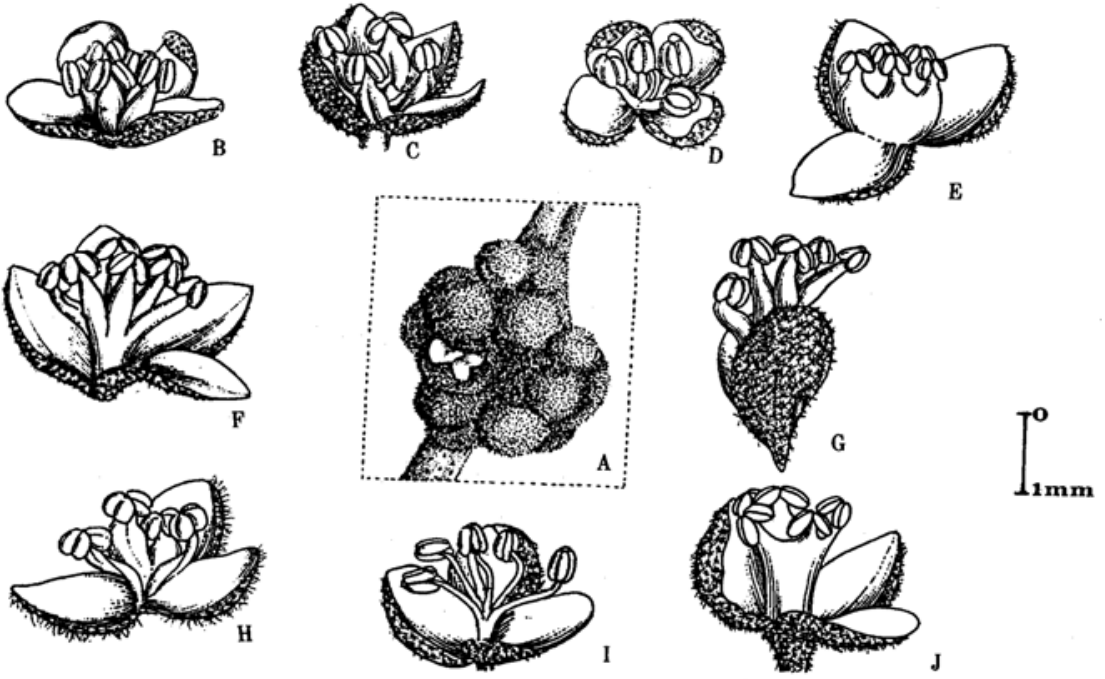

Figure 3. Variation of staminate flowers. A. Staminate inflorescences; B. $K$. bantamense; C. K. pectinatum; D. K. homalifolium; E. K. longifolium; F. K. brevipes var. brevipes; G. K. brevipes var. stenosepalum; H. K. frutescens; I. K. laevigatum; J. K. cordisepalum.
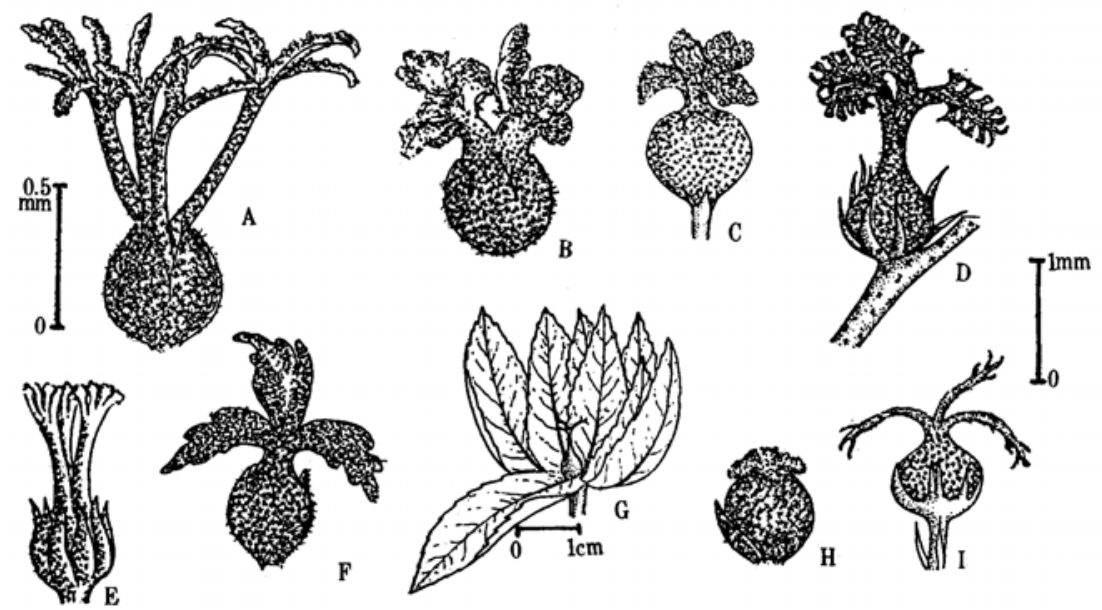

Figure 4. Variation of pistillate flowers of Koilodepas Hassk. A. K. cordisepalum; B. K. longifolium; C. K. bantamense; D. K. brevipes var. stenosepalum; E. K. brevipes var. brevipes; F. K. homalifolium; G. K. pectinatum; H. K. frutescens; I. $K$. laevigatum. Types of sepals: free $(A, D, E, G)$; connate $(C F H)$; subconnate $(B, I)$; types of styles: free $(A, I)$, connate $(B, C, D, E, F, G, H)$; types of stigma: antennate $(A, E, G, I) ;$ multifid $(B, F)$ and coralliform $(C, H)$.
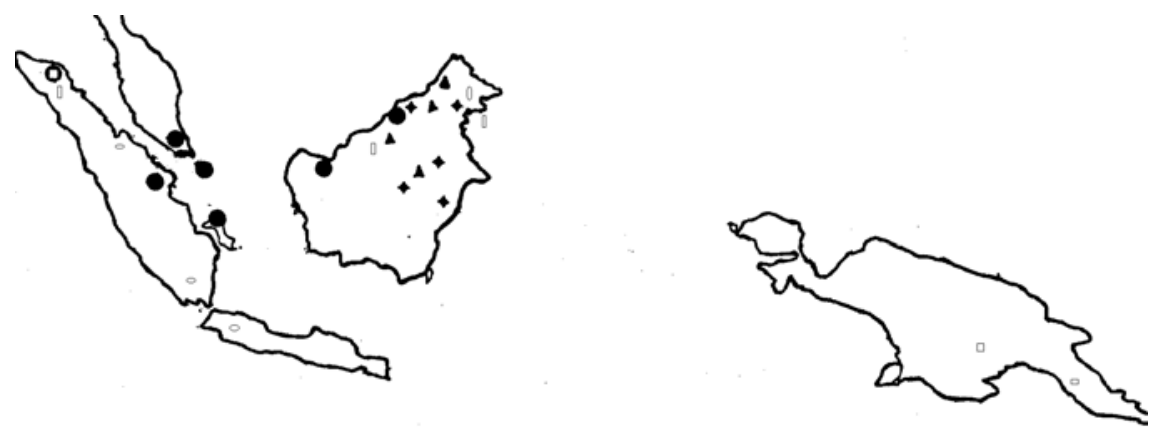

Figure 5. Distribution map of Koilodepas Hassk. $\circ=K$. bantamense; $=K$. brevipes; $\diamond=K$. pectinatum; $\mathbf{0}=K$. cordisepalum; $\mathbf{\Delta}=K$. laevigatum; $\bullet=K$. longifolium; $\square=K$. homalifolium; $\square=K$. frutescens.
Koilodepas is found in the phytogeograpic area Malesia. $K$. pectinatum, $K$. brevipes, and $K$. laevigatum are endemic in Borneo. $K$. bantamense is found in Java and Sumatra. $K$. longifolium is widespread in West Malesia (Malay Peninsula, Sumatra and Borneo) $K$. homalifolium is endemic in Papua New Guinea. K. cordisepalum is found, so far, only in Aceh (Figure 5.).

Phylogenetic analysis of Koilodepas

The phylogenetic analysis of Koilodepas was performed using 21 characters and the genus Cephalomappa as an outgroup (Table 3.). The letter was selected because it is classified in the Cephalomappinae as the sister sub tribe of the Epiprineae. Tribe Cephalomappa seems to be the SE Asian genus which shares most primitive characters with Koilodepas, e.g. staminate flowers in racemes, styles free, pistillate calyx not accrescent or involucrate, and the filaments inflexed in bud (Webster, 1994).

The analysis is performed using the Hennig 86 program with optional and all the characters unordered. Two cladogram (Figure 6.) were found 29 steps, consistency index $=0.93$ and retention index $=0.89$. This tree has short branch. $K$. brevipes as a primitive one and ending with the K. bantamense.

The outgroup is separated from Koilodepas by a plesiomorph character of the outgroup namely staminate flowers is sessile (6), surface of staminate is not stellate but lepidote (7), stipulate absent (9), surface of fruit is echinate (17), surface of stigma is papillate (20), sepal of pistillate flowers aestivation is valvate (15), and the inflorescences is racemose (19). $K$. brevipes is separated from the other Koilodepas by the stigma shape (8), the type of marginal stipules (11) and the inflorescences (19). The varieties is allied by number of abaxial glands (3), hairs on leaves (4), 


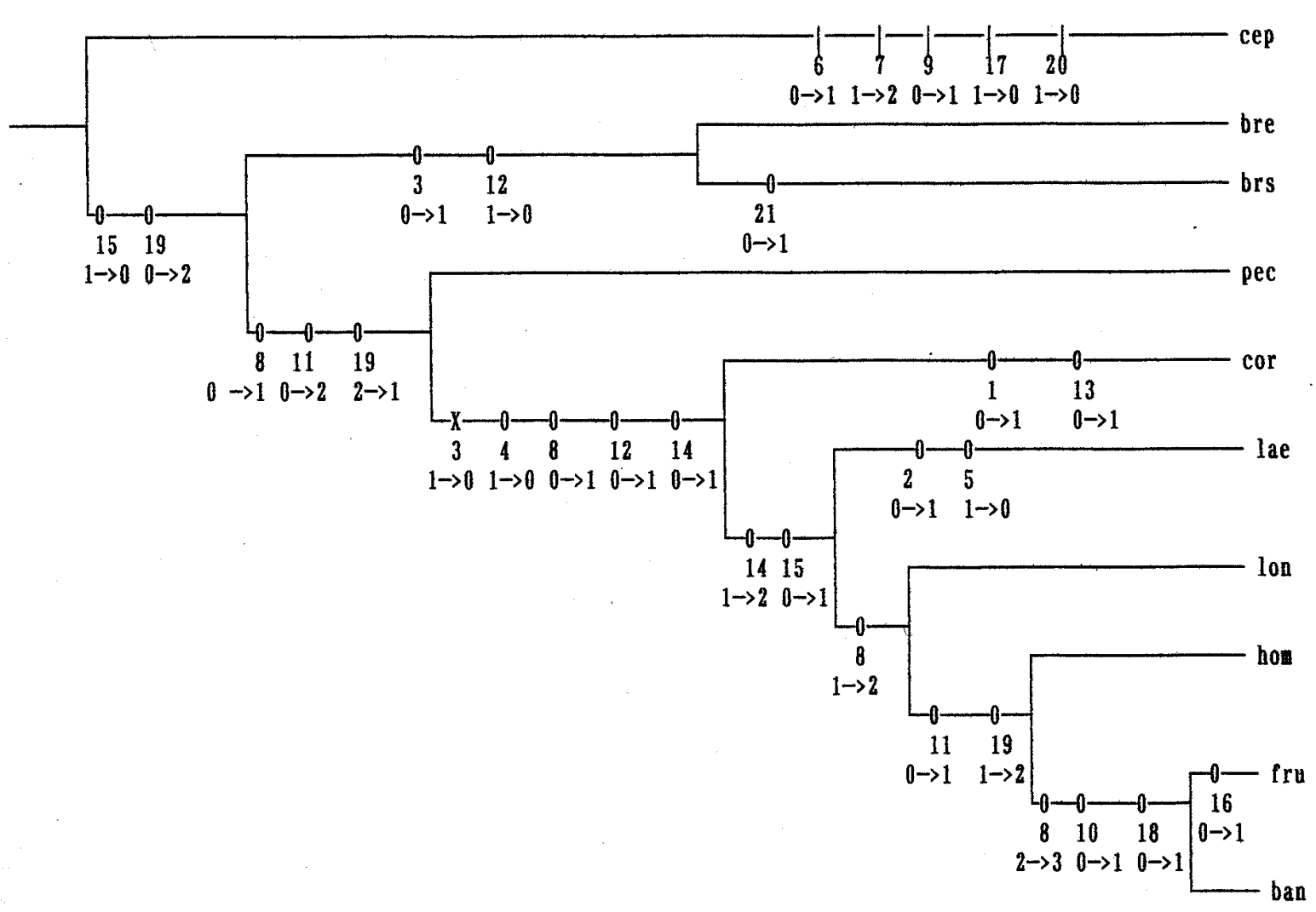

Figure 6. Dendrogram of Koilodepas Hassk. bre: $K$. brevipes var. brevipes; brs: $K$. brevipes var. stenosepalum; pec: $K$. pectinatum; cor: K. cordisepalum; lae: K. laevigatum; Ion: K. longifolium; hom: K. homalifolium; fru: K. frutescens; ban: K. bantamense.

stigma shape (8), petiolate length (12), and sepal shape of pistillate flowers (14). K. cordisepalum is separated from the other five Koilodepas by sepal shape of pistillate flowers (14), sepals of pistillate flowers (15), leaf shape (1), and venation (13). $K$. laevigatum is separated from the other species by stigma shape (4). $K$. longifolium is separated from the other two species by stigma shape (8), number of stigma (10), and styles (18). The last branch, $K$. frutescens is separated from $K$. bantamense by caducous stigma (16).

\section{Taxonomy}

Koilodepas Hassk., Bot. Zeit. (1856) 802; Hassk., Flora 40 (1857) 531 (Coelodpas); Retzia 1 (1858) 44; Miq., Fl. Ned. Ind I. (1859) 398; Hassk. Bull. Soc. Bot. Fr. 6 (1859) 713; Mull Arg. In DC. Prodr. 15. 2. (1866) 759; Baill., Hist. PI. 5 (1874) 220; Hook. F, Fl. Brit. Ind. 5 (1890) 419; Boerl., Handl. Fl. Ned. Indie. 3 (1) (1900) 196; Bourd. For. Trees Travancore (1908) 345; J.J. Sm, Meded. Depart. Landb. 12 (1910) 379; Koord., Exkursionsfl. Java (1912) 489; Pax \& K Hoofm. In Engl., Pflanzenr. Ed 4. 147. 7 (1914) 268; A.C. Sm, J. Arn. Arb. 23 (1942) 50; Pax \& K Hoffm. In Engl. \& Harms, Nat. Pflanzenfam. Ed. 2, 19C. (1931) 124; Airy Shaw, Kew Bull. 14 (1960) 283; Backer \& Bakhuin. Fl. Java 1 (1963) 486; Whitemore, Tree Fl. Malay 2 (1973) 103. Airy Shaw, Kew Bull. Add. Ser. 4 (1975) 138; Airy Shaw. Kew Bull. Add. Ser. 8 (1980)
128; Airy Shaw. Kew Bull. 36 (1981) 609. Type: Koilodepas bantamense Hassk.

\section{Description}

Tree, monoecious. Indumentum of short and long stellate hairs. Stipules: elliptical, subulate or cuneate, margin entire or pectinate. Leaves: alternate, simple; petioles terete or ungulate, basally and apically pulvinate; lamina elliptical, subcoriaceous to coriaceous, rarely chartaceous, at the base flat (elevated in K. brevipes), base round, with one pairs of glands on lower surface (K. brevipes with 3-7 pairs of glands); margin entire, crenate, dentate, or serrate, with glands on the lower surface; apex cuspidate or caudate; upper surface smooth, glabrous; venation pinnate, flat to raised above, raised below, submarginally looped, secondary and tertiary veins scalariform, quartenery veins reticulate. Inflorescences: axillary, spikes to simple panicles; pistillate flowers $1-3$ at the base and staminate flowers at the apex of the rachis. Bracts subulate to cuneate. Staminate flowers in glomerules, 7-10; calyx 3- or 4-merous, lobes rounded to acute, membranaceous, densely covered with stellate hairs; petals absent; stamens (3) 4-7 (10), filaments basally united, or spathulate ( $K$. laevigatum, subulate); anther sub-apically dorsifixed, latrorse, 2 locular, opening length-wise, smooth; pistillode 1 , small. Pistillate flowers: the sepal free, 5-9 lobes cordate or elliptical; 
margin entire to serrate, apex acute to obtuse, densely covered with stellate-tomentose; petals absent; ovary superior, densely tomentose, 3-locular; ovules 1 per locule; style short to long, terete, with stellate hairs; stigmas 3 or 6 , antennate, multifid or coralliform, persistent (coduceous in $K$. frutescens), apex bifid or bifurcate. Fruit: a rhegma, globular, 3lobed, tomentose, wall thick, glabrous inside, woody. Seeds: sub globular, surface smooth, glabrous, shining.

Distribution. 8 species in the Malay Peninsula, Sumatra, Java, Borneo, and Papua New Guinea.

Note: Leaf anatomy: abaxial surface of leaf hairy or glabrous; epidermis consisting of cells with sinuous to deeply sinuous anticline and slightly wavy walls; stomata elliptical.

Key to the species

1.a. Stipules elliptic, margin deeply and finely pectinate 1. K. pectinate

b. Stipules deltoid or triangular, margin entire to serrate

2.a. Stipules deltoid ................ 2

b. Stipules triangular .................. 5

3.a. Calyx of pistillate flowers connate 2. K. frutescens

b. Calyx of pistillate flowers subconnate ......................... 4

4.a. Filaments subulate, curveted; sepal of pistillate flowers with an aristate apex, stigma filamentose 3. K. laevigatum

b. Filaments spathulate, erected; sepal of pistillate flowers with an acute apex, stigma multifid ....... 4. K. longifolium

5.a. Sepal of pistillate flowers free, persistent

6

b. Sepal of pistillate flowers connate, caduceus ............. 8

6.a. Sepal of pistillate flowers cordate, apex of stigma antennate; indumentum of fruits with stellate hairs ........... 5. K. cordisepalum

b. Sepal of pistillate flowers elliptical, apex of stigma bifid or antennate; indumentum of fruits tomentose ............................ 7

7.a. Sepal of pistillate flowers with glands; stigma antennate; indumenta of leaf with stiff hairs in a rosette ...................... 6. K. brevipes var. stenosepalum

b. Sepal of pistillate flowers no glands, stigma bifid; indumentum of leaf with stiff single stellate hairs ................................. 7. K. brevipes var. brevipes

8.a. Sepal of pistillate flowers with 9 lobes, apex acute, stigma coralliform ..... 8. K. bantamense

b. Sepal of pistillate flowers with 6 lobes, apex obtuse, stigma multifid .............................. 9. K. homalifolium
The description of three species can be seen below, i.e. Koilodepas bantamense Hassk., Koilodepas brevipes Merr. var. brevipes, Koilodepas brevipes Merr. var. stenosepalum (Airy Shaw) Airy Shaw, and Koilodepas frutescens (Blume.) Airy Shaw.

\section{Koilodepas bantamense Hassk}

Koilodepas bantamense Hassk., Bot. Zeit. 14 (1856) 802; Retzia 1 (1858) 45; Mull.Aarg. in DC., Prodr. 15 (2) (1866) 759; Engl. \& Prantl, Nat. Pflanzenfam. (1896) 51; Boerl., Handl. Fl. Ned. Indie. 3 (1900) 286; J.J.Sm., Meded. Depart. Landb. 12 (1910) 380; Koord., Exkursionfl. Java 2 (1912) 489; Pax \& K.Hoffm. in Engl., Pflanzenr. 4 (1914) 269; Planten. Bot. Gard. (1926) 291; Pax \& K.Hoffm. in Engl. \& Harms, Nat. Pflanzenfam. Ed. 2. 19c (1931) 125; A.C. Sm, J. Arn. Arb. 23 (1942); Airy Shaw, Kew Bull. 14. (1960) 384; Backer \& Bakh. Brink., Fl. Java. 1 (1968) 486. Type: Hasskarl s.n. (L-holo). West Java, Banten (Figure 7-8).

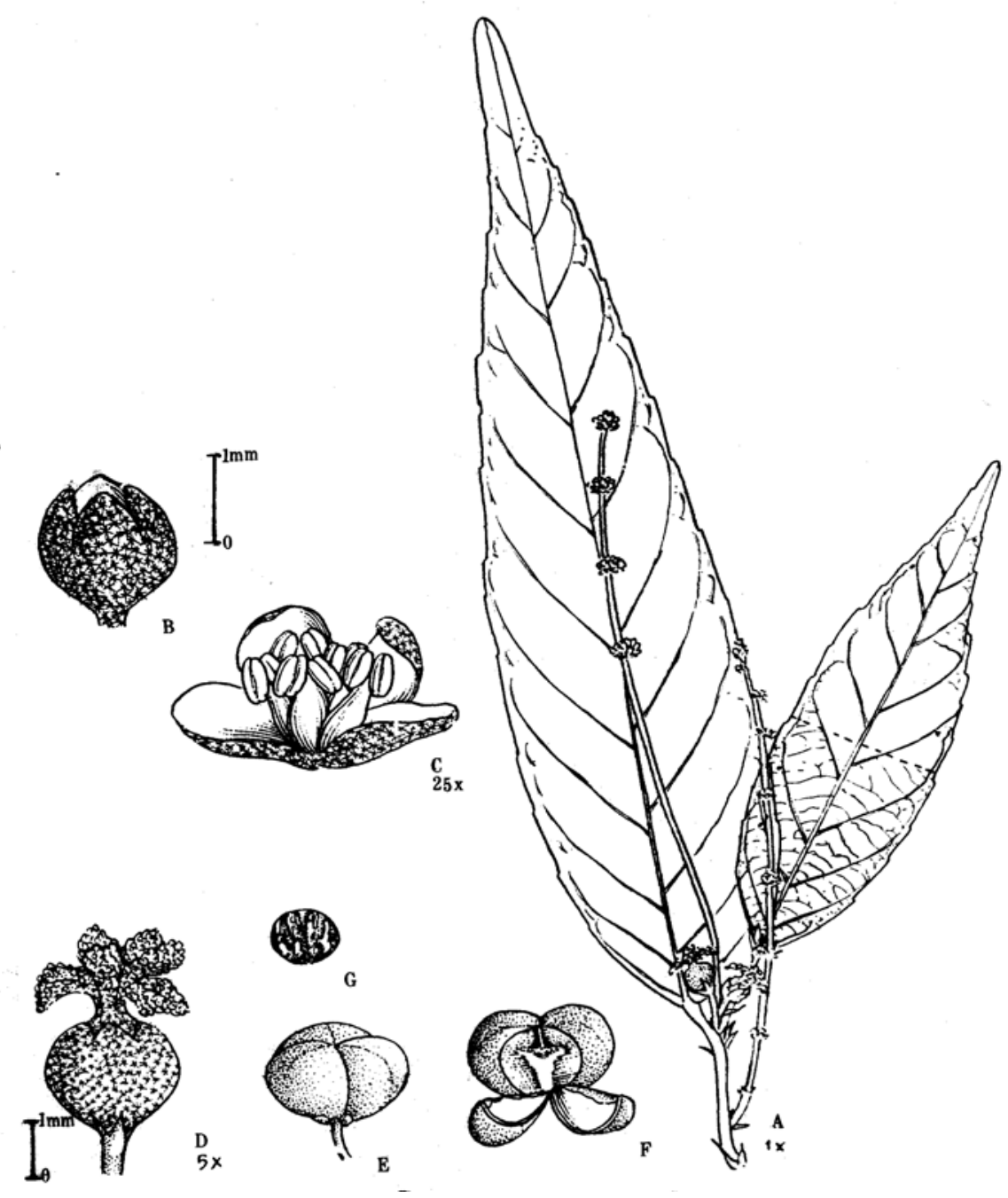

Figure 7. K. bantamense Hassk. A. twig with inflorescences; B. calyx of staminate flower; C. staminate flower; D. pistillate flower; E. frit; F. opened fruit; G. seed with brown dots (after Forbes 1532, BO). 


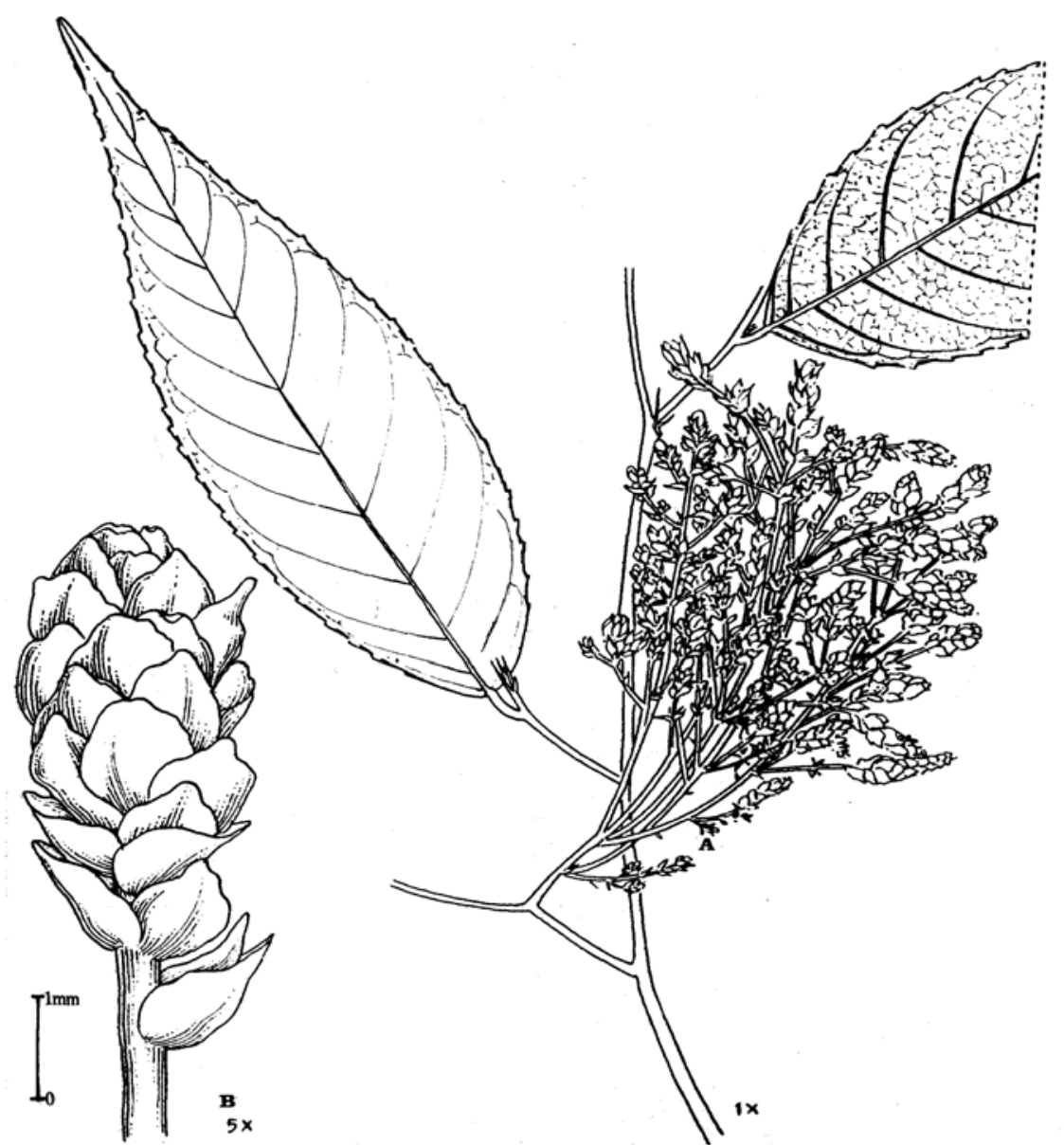

Figure 8. K. bantamense Hassk. A. twig with abnormal inflorescence; B. abnormal spike (after Lorzing 5615, BO).

Tree. Branches smooth, densely covered with stellate hairs. Leaves: stipules $4-5$ by $0.5 \mathrm{~mm}$, subulate, erect, outside with grooves, covered with stellate hairs, margin serrate, apically aristate; petioles $6-8$ by $1.2 \mathrm{~mm}$, sulcatus, densely with stellate hairs. Lamina elliptical, recurved, $8-22.5$ by $1.8-5 \mathrm{~cm}$, subcoriaceous; base obtuse to acute, with two glands on lower surface; margin dentate but basally entire; glands in every tooth; apex acuminate to cuspidate, upper surface glabrous; lower surface scabrous, with minute stellate hairs; venation on both sides, especially basally, nerves 12-14 pairs, submarginally looped, veins scalariform. Inflorescences 5-8 cm long; with the two or three spikes together; bracts, subulate, 1-5 mm long, glabrous, margin entire, apex acuminate; staminate part, sub globular, c. 2 by 2.5 $\mathrm{mm}$, consisting of 7-25 flowers. Staminate flowers: bracts. ovate c. 1.4 by $0.3 \mathrm{~mm}$, ovate, glabrous, margin entire; calyx 3-4 lobed, tube c. 0.4 by $1 \mathrm{~mm}$; lobes c. 0.85 by $0.35 \mathrm{~mm}$, smooth, apex acute; Stamens (3) 4 or 5 (6); filaments $0.9-1.5 \mathrm{~mm}$ long, androphore 0.3-0.6 mm long, spathulate, pistillode c. $0.1 \mathrm{~mm}$ long. Pistillate flowers: pedicles 0.4-0.6 mm longs, sometimes sessile, glabrous; bract ovate. c. 1.0 by $0.3 \mathrm{~mm}$, glabrous, apex acute; calyx enclosing ovary, 2-2.25 by c. $2 \mathrm{~mm}$, 9-lobed, with densely stellate hairs, apex acute, sometimes with glands between the lobes; ovary $2-3$ by 2-2.5 $\mathrm{mm}$, stigmas $6,1.5-2$ by c. 4 $\mathrm{mm}$, coralliform; style absent; densely stellately to tomentosely hairy. Fruit; globose c. 1.4 by 1.5 cm, outside smooth; mesocarp, $2.5 \mathrm{~mm}$ thick. Seed sub globular, c. 1 by $1 \mathrm{~cm}$.

Distribution. West Java: Banten, Pelabuhan Ratu; Sumatra: Lampung; North Sumatra: Sibolangit (Figure 9).

Habitat: primary forest, alt: 350-500 m asl.

Note: Specimens of Lorzing $5092,5615,16329$ have abnormal form of flowers. Both the staminate and pistillate flowers have 7 or 9 interested calines on one axis. This phenomenon may be caused by insect damage, similar to Myrsine avenis (Sunarno in Sunarti, 1987).

\section{Koilodepas brevipes Merr.}

Koilodepas brevipes Merr., Philipp. J. Sci. 30 (1926) 80; Airy Shaw, Kew Bull. 14 (3) (1960) 389. Kew Bull. Add. Ser 4 (1975) 138 Type: D.D. Wood 1291 (BOholo, K-iso), Borneo (Figure 11.).

Shrub to tree, up to $10 \mathrm{~m}$; dbh up to $20 \mathrm{~cm}$, bark rough. Leaves: stipules subulate, 5-12 by c. $1 \mathrm{~mm}$, margin entire, apex aristate to acuminate; petioles $2-10$ by $1.5-3$ $\mathrm{mm}$, covered with dense short stellate hairs; lamina elliptical to above; $10-33$ by $3.5-9 \mathrm{~cm}$; coriaceous; basally attenuate, with 3-7 pairs of glands; margin dentate to serrate; glands in every apex of nerves the margin, apex caudate; upper surface glabrous, lower surface scabrous, densely covered by long and short

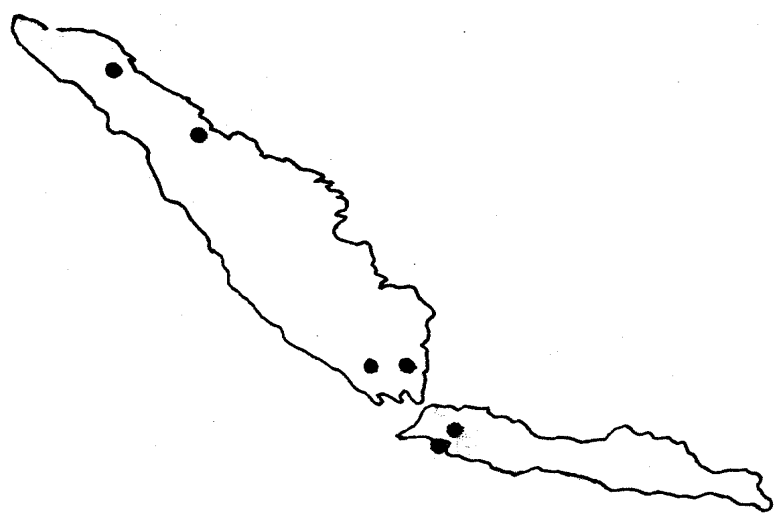

Figure 9. Distribution map of $K$. bantamense Hassk. 
stellate hairs; nerves 11-14 on either side, arching at apex, submarginally looped, veins scalariform. Inflorescences: spikes up to $10 \mathrm{~cm}$ long; at the base of rachis 1-3 pistillate flowers; bracts cuneate, 0.7-1 mm, densely covered with stellate hairs, apex acute; 2 glands at the base; staminate glomerulus, subglobose, c.2 by $2 \mathrm{~mm}$, consisting of 6-10 flowers. Staminate flowers: bracts cuneate, apex acute, densely civered with stellate hairs; calyx tube $0.5-0.7 \mathrm{~mm}$ long, lobes 3 , 0.2-0.5 mm long, apex acute; densely with stellate hairs; stamens 4-7; filament 1-2.25 mm long, basal connate, terete, androphore 0.1-1.75 mm long; pistillode $0.2-0.8 \mathrm{~mm}$ long. Pistillate flowers: bracts 1 , cuneate, $0.5-1$ by $1.5-2 \mathrm{~mm}$ long. Apex acute to acuminate, mostly glands at base; calyx 609 lobed, likes elliptical, $2-15$ by $1-2 \mathrm{~mm}$; covered with stellate hairs; glands at base. Ovary c. 2 by $2 \mathrm{~mm}$; style 1-3 mm long, terete, covered with stellate hairs; stigmas $3,0.5-8 \mathrm{~mm}$ long, antennate or multifid. Fruit, globular c. 2 by $5 \mathrm{~mm}$, smooth, shining, brown dotted.

Distribution: Kalimantan

(Borneo) (Figure 10).

Habitat. Found in primary lowland forest on dry land, rolling hills and ridges. On sand stone, sand, (yellowish) black soil, yellow red soil. Altitude 30 to $300 \mathrm{~m}$ asl.

Vernacular names: kayu gading (Kutai); ulas (Malay and Suluk).

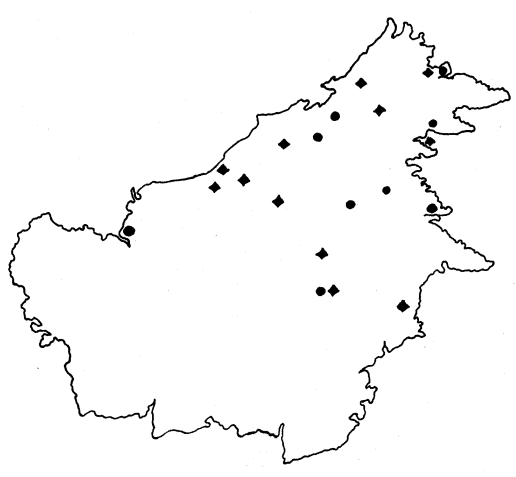

Figure 10. Distribution map of $K$. brevipes Merr. $\bullet=K$. brevipes var. brevipes; $\downarrow K$. brevipes var. stenosepalum.

\section{Key identification to the varieties of $\mathrm{K}$. brevipes}

1.a. Sepals of pistillate flowers with glands at base; apex of stigma antennate; indumentum of leaves with stellate hairs in rosettes. var. stenosepalum

b. Sepals of pistillate flowers without at base apex of stigma bifid; indumentum of leaves with stiff single stellate hairs var. brevipes

\section{Koilodepas brevipes var. stenosepalum}

K. brevipes var. stenosepalum (Airy Shaw) Airy Shaw, Kew. Bull. Add. Ser. 4 (1975) 138- K. stenosepalum Airy Shaw, Kew Bull. 14 (1960) 390; Kew Bull. 16 (1963) 356. Type: L.L. Forman 442 (BOholo; L-iso) Borneo, Belayan River, Gunung Sahari (Figure 12.).

Leaves: petioles ungulate, 3-6 by 1-3 $\mathrm{mm}$; lamina elliptical, c $0-33$ by $4-9 \mathrm{~cm}$; base attenuate; margin dentate; apex caudate; surface basally covered with long stellate hairs. Inflorescences: spikes, 4-10 cm long, staminate flowers in glomerulus 3-4 by c. $4 \mathrm{~mm}$, sessile; calyx 3-lobed; $1.5-2.5$ by $0.9-1.5 \mathrm{~mm}$; apex acute; tube $1-1.5$ by c. $1 \mathrm{~mm}$, lobes c. 1 by $1.5 \mathrm{~mm}$, densely covered with stellate hairs; stamens 4-6; androphore 0.5-1.75 mm long; filament 1.9-2.55 mm 


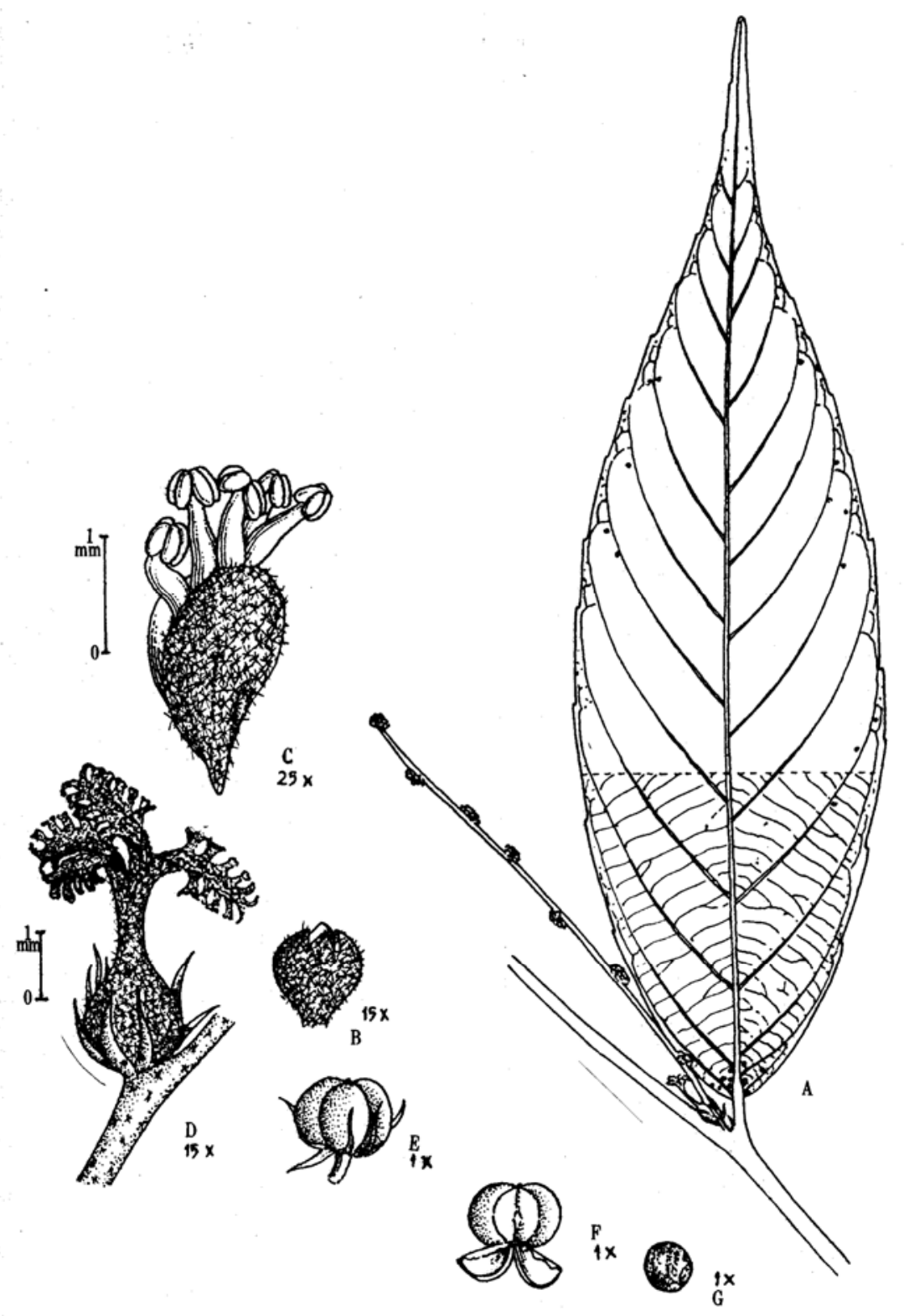

Figure 12. K. brevipes var. stenosepalum (Airy Shaw) Airy Shaw. A. twig with inflorescences; B. calyx of staminate flower; $C$. staminate flower; D. pistillate flower; E. fruit; F. opened fruit; G. seed (A,E,F,G: after L.L. Forman 442, BO; C,D: after Kostermans 13949, BO,L)

long; pistillode 1-1.2 mm long, apex bifid. Pistillate flowers: sessile; calyx persistent; tube with the top distinctly segment, subulate; 6-9-lobed; $10-15$ by 1 $1.5 \mathrm{~mm}$, covered with stellate hairs, glands at base; ovary c. 2 by $2 \mathrm{~mm}$; style terete, $1-4 \mathrm{~mm}$ long; stigmas 3, 1.8-8 mm long, antennate or multifid. Fruit: c. 1.5 by $1.5 \mathrm{~cm}$. Seed sub globular, c. 1 by $1.2 \mathrm{~cm}$.

\section{Koilodepas frutescens (Blume.) Airy Shaw}

K. frutescens (BI.) Airy Shaw, Kew Bull. 14 (3) (1960) 385; Airy Shaw, Kew Bull. Add. Ser. 4 (1975) 138. Airy Shaw, Calpigyne frutescens Blume, Mus. Bot. Lugd. Bot. 2 (1956) 193; Mull.Arg. in DC., Prodr. 15 (2) (1866) 1255; Pax \& K. Hoffm. In Engl.,
Pflanzenr. IV. 147. VII (1914) 255; XIV (1(19) 35; Merr., J. As. Soc. Str. Br. (1921) 343. Ptychopyxis frutescens (Blume) Croizat, J. Arnold Arb. 23 (1942) 49. Type: G. Pomathus s.n. (L-holo) Borneo, Banjarmasin (Figure 14.).

Small tree up to $12 \mathrm{~m}$ high, dbh 20-50 cm; bark rough. Leaves: stipules cuneate to subulate, $3-5$ by $0.5-1 \mathrm{~mm}$, margin entire or serrate, apex aristate; petioles $5-13$ by $1-2.5 \mathrm{~mm}$; lamina: elliptical to ovate, 8-17.5 by $2.5-5.5 \mathrm{~cm}$, subcoriaceous, base cuneate; margin entire to serrate, apex acute; both surface glabrous; nerves 9-15, submarginallly looped, secondary and tertiary veins scalariform. Inflorescences: spikes or simple panicles, with 3-5 rachises, 7-13 $\mathrm{cm}$ long. Staminate glomerulus sub globular, $2-2.5$ by $1.5-3 \mathrm{~mm}$, with 10-20 flowers; bract cuneate, 1-2 by 1-1.5 mm, apex acute; staminate flowers; tube $1.7-2$ by 1.7-1.8 mm, lobes 0.5-0.6 mm long, membranaceous, densely stellate hairy; stamens 4-5; androphore $0.1-0.5 \mathrm{~mm}$ long; filaments spathulate, $0.5-2 \mathrm{~mm}$ long; pistillode $0.2-0.3 \mathrm{~mm}$ long. Pistillate flower: densely stellately to tomentosely hairy; bract 3 and 2 bracteoles, $1,2-4$ by c. $2 \mathrm{~mm}$, bracteoles very short, cuneate, margin entire, apex acute, densely tomentose; calyx 7-lobed, tube c. 4 by $3 \mathrm{~mm}$; apex obtuse; ovary $3-$ 3.5 by $2.5-3 \mathrm{~mm}$, densely tomentose; styles absent; stigmas 6 , coralliform, 4 by $3 \mathrm{~mm}$, caduceus. Fruit: c. 1.5 by $1.9 \mathrm{~cm}$; peduncle $5-6$ by $2.5-3 \mathrm{~mm}$;
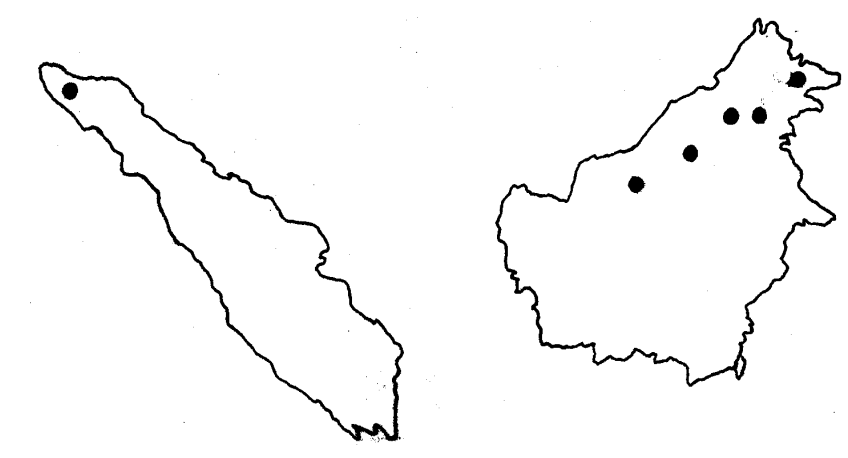

Figure 13. Distribution map of $K$. frutescens (Blume) Airy Shaw. 
mesocarp 2.5-2.8 mm thick; inside smooth, densely tomentose. Seed sub globular, c. 1.6 by $8 \mathrm{~mm}$.

Distribution. N. Sumatra (Aceh) and N. \& N.E; Borneo (Figure 13.).

Habitat: Primary forest, hill top, blackish soil, dry land; rolling hill, yellow-red loamy soil. Alt: $80-600$ $\mathrm{m}$ asl.

\section{ACKNOWLEDGEMENTS}

The first author (M) would like to express her gratitude to Prof. Dr. Ir. Edi Guhardja, M.Sc., for the use of research facilities in the Post Graduate Programme, the Bogor Agriculture University and Dr. Johanis P. Mogea, Director of the Herbarium of Kew $(\mathrm{K})$, and Director of the Rijksherbarium/ Hortus Botanicus Leiden (L) for sending specimens on loan. She was under deep obligation to Prof. Dr. Ir. Edi Guhardja, M.Sc., Prof. Dr. Mien A. Rifai and Dr. Johanis $P$. Mogea under whose supervisor this study has been carried out. She was also very grateful to Dr. Peter van Walzen (Rijksherbarium, Leiden) for some constructive discussions and valuable assistance as well as criticism freely given during the course of this study and writing of the manuscript. Moreover, She had to thank Mintoro Priyadi, M.Si for preparing media and picture setting, and Drs. Sukarna MA, Director of the Education Science Institute in Medan for continously, encouraging her in this study.

\section{REFERENCE}

Airy Shaw, H.K. 1960. Note on Malaysian Euphorbiaceae. Kew Bulletin 14 (3): 381-391.

Airy Shaw, H.K. 1963. Note on Malaysian and other Asiatic Euphorbiaceae. Kew Bulletin. 16: 352-370.

Airy Shaw, H.K. 1969. Note on Malaysian Euphorbiaceae. Kew Bulletin. 23: 82-89.

Airy Shaw, H.K. 1975. The Euphorbiaceae of Borneo. Kew Bulletin. Additional Serie 4: 137-149.

Airy Shaw, H.K. 1981. Note on Malaysian Euphorbiaceae. Kew Bulletin. 36 (3): 609-615.
Croizat, L. 1942. Euphorbiaceae from the far East. Journal of the Arnold Arboretum 23: 45-67.

Hasskarl, J.K. 1856. Bot. Zeit. 14:802.

Hasskarl, J.K. 1858. Hortus Bogoriensis Descriptus Amstelodami. Sumptibus F. Gunst.44-50.

Hasskarl, J.K. 1859. Revisio Euphorbiacearum, quas nuper in Retzia et Horto Bogoriensis Descriptio. Bull. Soc. Bot. Fr. 6: 712-719.

Hooker, J.D. 1890. Flora of Britis India. East Indian Compagny. 5: 419.

Merrill, E.D. 1916. Euphoebiaceae. The Philippines Journal of Science 11: 66 .

Merrill, E.D. 1926. Euphoebiaceae. The Philippines Journal of Science30: 67-81.

Pax and Hoffm, K. 1914. Das Pflanzenreich IV. 147. VII: 269

Rifai, M.A. 1976. Sendi-sendi Botani Sistematika. Lembaga Biologi Nasional- LIPI.

Smith, J.J. 1910. Euphorbiaceae. In: S.H. Kooders \& Th. Valeton (eds): Bijdrage 12 Tot de kennis der boomsoorten op Java. Meded. Dep. Landbouw 10: 379-383.

Sunarti, S. 1987. Anatomi daun dan Taksonomi duku, kokosan dan pisitas. Floribunda. 1 (4): 1-3.

Whitmore, T.C. 1973. Tree Flora of Malaya. 2: 34-105

Webster, G.L. 1994. Systematics of the Euphorbiaceae. Annals of Missouri Botanical Garden 81 (11): 79. 